\title{
ОСОБЛИВОСТІ ФУНКЦІОНУВАННЯ ПАРЦЕЛЬОВАНИХ КОНСТРУКЦІЙ У ХУДОЖНЬОМУ ТЕКСТІ
}

\author{
Вавринюк Т. І. Особливості функціонування парцельованих конструкцій у \\ художньому тексті. \\ У статті розглядаються структурно-стилістичні особливості парцеляції в \\ сучасному художньому тексті. Визначено природу i суть парцеляції як одиниці \\ експресивного синтаксису, розглянуто основні типи парцелятів та прокоментовано їх \\ функціональні властивості. \\ Ключові слова: парцеляція, експресивний синтаксис, головні члени речення, \\ другорядні члени речення, синтаксична конструкція.
}

Вавринюк Т. И. Особенности функционирования парцеллированных конструкций в художественном тексте.

В статье рассматриваются структурно-стилистические особенности парцеллирования в современном художественном тексте. Определены природа и сущность парцеллирования как единицы експрессивного синтаксиса, рассмотрены основные типы парцеллятов и прокоментированы их функциональные качества.

Ключевые слова: парцелляция, экспрессивный синтаксис, главные члены предложения, второстепенные члены предложения, синтаксическая конструкция.

Vavrynyuk T. I. Specific features of the parceling constructions in modern literary text.

The article is dedicated to the analysis of the structural and stylistic particularities of parceling constructions in modern literary text. The essence of the parceling phenomena as means of expressive syntax is specified, the basic types of parceling are determined and the principal stylistic functions of parceling are described.

Key words: parceling, expressive syntax, principal and secondary parts of sentence, syntax construction.

Засобом експресивного синтаксису в мові художніх творів $\epsilon$ парцельовані конструкції, які передають авторську оцінку, актуалізують окремі смислові компоненти висловленого. У дослідженні спираємося на погляди тих мовознавців, які пов'язують це явище 3 комунікативнофункціональним планом речення та розглядають його на загальному тлі 
об’єктивної та суб'єктивної модальності (К. Городенська, А. Загнітко, С. Срмоленко, І. Попова, С. Марич, Л. Конюхова, Т. Шевченко та ін.).

Услід за А. Загнітком, парцелятом вважаємо частину простого або складного речення, утворену при його членуванні на кілька висловлень у зв'язку з певною комунікативною ідеєю й винесену на межі синтаксичної структури-речення [2, с. 201]. Таке членування передбачає відповідне інтонаційне оформлення, за якого позиція читача неодмінно «підхопить» позицію автора. Отже, парцеляцію можна віднести до мовленнєвих репрезентантів автора, який керується певними комунікативнопрагматичними настановами і виокремлює ті чи ті сегменти. Наприклад: Його повезли підводою. Капрал і рядовик [7, с. 91]; У монастирській изеркві на самому переді в шапках два матроси під час служби курять цигарки. Курять і просміхаються (1, 94); Гнат вже один. Сидить і думас [5, с. 130].

Парцеляція - це явище динамічного (експресивного) синтаксису, яке виражається в структурно-семантичному та інтонаційному вичленуванні однієї або кількох синтагм (чи речень), що обов'язково виносяться за межі речення і розташовуються в постпозиції стосовно базового речення (бази). Базове речення в поєднанні з парцелятом в роботі визначається терміном «висловлення», відповідності до трактування цього терміна представниками Празької лінгвістичної школи [3, с. 5]. Парцеляція є одним із засобів актуального членування, оскільки відділений компонент виступає ремою.

На рівні простого речення парцелюванню підлягають переважно усі члени речення. У досліджених текстах високою частотністю функціонування відзначаються конструкції 3 парцельованими простими присудками. Оскільки за синтаксичною роллю в реченні жоден член речення не може зрівнятися 3 присудком за його функціонально-комунікативним навантаженням [3, 221], то речення 3 парцельованими присудками мають особливі експресивні можливості: Спини не маєш часу розігнути. Мартин, знаєте ж?.. Господар [1, с. 13]; Люди не рухнули. Чекають [1, с. 13].

Серед парцельованих присудків, як засвідчують спостереження, найчастіше піддаються парцельованню однорідні присудки одного виду і часу: Ступала, йшла, бігла бійцем. Поспішала, квапилась [7, с. 194]; -...А сіль ви маєте? - заглянув у жолоб. - Солі ще досить. Стане [1, с. 178].

$\mathrm{У}$ наведених прикладах парцеляти називають дію, яка 3 погляду мовця (автора-оповідача чи героя твору) є важливою в момент висловлювання, а це сприяє легшому сприйняттю контексту читачем чи слухачем.

Парцеляти можуть містити повтор присудків. Парцельований повторюваний присудок переважно має значення доповнення, уточнення. Наприклад: Йдуть, як дорослі, як старі. Йдуть і розважсають [1, с. 19]; (․ Т. І. Вавринюк, 2015. 
Просив же він. Щоб купили йому чоботи, щуоб не був вічно босий? Просив [1, с. 147]; Бог не почує? Почує [1, с. 333]; Я носив. І носитиму [7, с. 301].

Відносна самостійність у реченнєвій структурі однорідних та відокремлених другорядних членів речення сприяє їх парцелюванню. Наприклад: 3'являється гармонія, чарка і славетна ковбаса. Пахуча, смажсена з цибулькою, ще й приперчена [1, с. 14]; Сади обтяжені яблуками і сливами. Сині такі, повні і соковиті... [1, с. 40]; Бери, людино, святий хліб, переломлюй $і$ ӥж. М'який, пахучий, смаковитий [1, с. 65]; Нi, він ніколи, ніколи не перестане любити життя. Болюче, розкіине, соковите! [1, с. 298].

Парцельовані відокремлені означення увиразнюють якісну характеристику предмета, названого субстантивом у базовій частині конструкції. У ролі парцелятів можуть виступати узгоджені й неузгоджені означення, наприклад: Подумати тільки, яка земля. Підсоння, новина, вигносна, вироблена, без пнів [1, с. 175]; Арсен тільки виткнувся на дорогу, а навпроти Володька. Перестраханий, без лиця [7, с. 38]; Їі будинок - учительський, збудовано перед війною. Одноповерховий, під бляхою, з синіми ганками, синіми віконницями, зараз облуплений $\boldsymbol{i}$ занехаяний [1, с. 115].

На відміну від означень, у додатків виявляється набагато менша здатність до відокремлення у фразі. Парцелюються як прямі, так і непрямі додатки: Повантажували вози різним майном, свати шугали потай по домашиному господарстві $i$ щуо могли похопити, перли $i$ пакували на підводи. Кури, гуси, якісь коноплі, стару ступу [1, с. 35]; А сироті чого треба? Ласки, доброго слова [7, с. 38]; Я піду, мамо, на Різдво колядувати. До мельника, до побережника [1, с. 186]; А де посіяно мак, понатикано квасолю й біб - прикрито гіллям-галуззям. Від курей [7, с. 421]; Крім того, щчо одержав наступне звання, про нього з'явилася стаття в газеті. 3 портретом [5, с. 112]; Звичайно, хто більше прачює, той більше і одержує. Але тільки грочей. Без комфортабельних лікарень і пайків [7, с. 38]. Такі конструкції в контексті досліджуваних творів конкретизують, уточнюють, доповнюють предикат, що міститься у базовій частині.

Піддаються парцелюванню також обставини:

- способу дії, актуалізуючи якість дії, стану, ознаки та способу їх вияву, наприклад: Як вчинив колись Скрипник... Просто й недійно, без допитів, принижень, знущань [5, с. 110]; Рука, нишпорячи, хапала вугілля навпомачки. Вправно й непомильно [7, с. 264];

- місця: А скрізь повно чужих людей. I на лавах, $\boldsymbol{i}$ за столом, $\boldsymbol{i}$ в зачіпку [1, с. 10]; Мартин Заруба мав дві господарки. У селі й на хуторі 
[1, с. 13]; То далеко. Звідсіль не зобачиш. За морем [1, с. 190]; - Та то там... Коло Києва [1, с. 192]; Зненацька з боку шосе почувся собачий гавкіт. Із зовсім протилежнного боку [6, с. 223];

- часу і мети: День, вечір, ніч, а там - суд. У неділю [7, с. 32]; I вона думала, шуо він у неї мужній. До сьогодні [7, с. 82]; Поліцай з гарнізонной кухні приносив їй їсти, але не їла. Добу, півтори [7, с. 177]; Восени ӥм нарізали город. На ньому трішки посіяли жита, соток із десять. П'ятнадиять залишилось. Під картоплю [7, с. 429]; При першому знайомстві дав їй усі свої можливі телефони. Про всяк випадок [5, с. 106]; Коли намалює, принесеш картину до мене. Для затвердження [5, с. 130].

Парцеляція підвищує експресивну наголошеність кожного елемента висловлення, підсилює напруженість думки, сприяє створенню своєрідної ритмомелодики тексту. Така форма побудови синтаксичних конструкцій допомагає глибше зрозуміти зміст, дає змогу автору висловити своє ставлення до зображуваного, а читачеві краще зрозуміти авторську оцінку.

У складнопідрядних реченнях парцеляції підлягають найчастіше детермінантні предикативні частини. Наприклад: I ще подумав: $i \mathrm{mu}$, Володимире Петровичу, фактично доклав до иього рук. Бо мовчав $\boldsymbol{i}$ мовчиш [5, с. 75]; Це вихопилося в нього мимоволі, як крик душі, як щзось неймовірне, несамовите. Бо не хотів нікому зраджувати свойх почуттів [5, с. 113]; Миша, мрукаючи, сиділа, не втікала. Ніби знала, щцо Володька не накричить, не потягне їі чимось важким, боячись наробити гаму [7, с. 154].

У досліджених художніх текстах помітне місце посідають парцельовані складнопідрядні речення з підрядними мети: Уявіть собі таке: у союзний Наркомат внутрішніх справ надходить повідомлення про те, щуо капітан держбезпеки Сокирко тісно зв'язаний з запеклим ворогом народу колишнім заступником наркома Онищенком, а син Онищенка, переслідуючи свої ворожі й шпигунські інтереси, написав про Сокирка в газету статтю. Щоб прославити свого підручного, просунути по службі [5, с. 132]; Сьогодні неділя $і$ навіть енкаведисти відпочивають - що ж, також люди, і нехай їм сняться гарні сни. Щоб 3 новими силами й новою енергісю викорчовувати бур'яни на неозорій та пишній ниві [5, с. 138]; В узвозі завжди стояло болото. Тому було вимощено дощатий хідник [7, с. 116].

Актуалізованою експресивністю характеризуються складнопідрядні речення 3 парцелюванням підрядних допустових. Зауважимо, що найчастіше парцелюються складнопідрядні речення, підрядна допустова частина яких пов'язується сполучником хоч. Наприклад: Німещь спокійно,

(․ Т. І. Вавринюк, 2015. 
як належить, одягнув усе, обтріпав капелюха, сердито поправив пір'їнку. Хоча руки в нього помітно тремтіли [1, с. 198]; Не загинув тільки він, Тренкер. Хоч був спочатку одним із Ремових помічників [5, с. 206].

Парцеляція підрядної допустової частини дає змогу виразно наголосити на тому, що дія головної частини складного речення відбувається всупереч умовам дії, вираженої в підрядній частині.

Потужними експресемами в художньому мовленні $\epsilon$ також складнопідрядні речення 3 парцельованими підрядним порівняльним: I стояли на хатньому порозі ковалиха з коваленятами. Мов позаклякали [7, с. 241]; Він вишукував картопельки за сестрою $і$ бабунею. Немов той справжній господар, який боявся, щоб не пропала мізерія добра [7, с. 314]; Вона мовчки виманює до себе Катрю. Ніби кличе кудись [7, с. 397].

У всіх зазначених ситуаціях парцельована підрядна частина скоординована з попередньою головною, граматично залежить від неї й структурно не відрізняється від непарцельованої підрядної.

У складносурядних реченнях парцеляція виконує функцію загальної експресії. Частотними у функціональному плані $є$ парцельовані складносурядні речення $з$ протиставними сполучниками. Наприклад: Tym, власне, мали зустріти Арні з його грузовичком. Проте Арні чомусь не було видко [6, с. 198]; Можна було рушати в дорогу. Проте лісник щцось мав іще залагодити [6, с. 228]; Можна було й рушати. Проте лісник вирішив, щзо справу ще не закінчено [6, с. 230]. Парцеляція складносурядних речень iз розділовими сполучниками дає змогу загострити увагу читача на семантичній важливості кожного парцелята зокрема, показати різні можливості розв'язання якогось питання, іноді вказати на сумнів.

Хоч за сукупністю i функціональними типами сурядних сполучників, складносурядні речення виявляють граматичну подібність до простих речень, але сурядні частини у складносурядному реченні мають більшу синтаксичну незалежність, ніж однорідні члени у простому ускладненому реченні. Сурядні частини складних речень безпосередньо вступають у сурядний зв'язок без посередництва інших компонентів. А це, звичайно, полегшує умови парцелювання.

Отже, парцеляція - явище багатофункціональне й багатопланове. У мові художнього тексту парцеляція виконує експресивну функцію, яка виявляється у виокремленні одного речення або тільки відрізків речення в окрему самостійну частину, створює несподівану паузу, що посилює експресію несподіваної дії або ефект тривалості. Водночас парцеляція членує текст, підкреслює його смислові центри, створює несподівану паузу, перебіг ритму. 


\section{Література}

1. Бедзик Ю. Д. Чорний лабіринт, або Довгий шлях в Альпи : [роман] / Ю. Д. Бедзик. - К. : Воєнвидав, 1991. - 320 с.

2. Загнітко А. П. Основи українського теоретичного синтаксису / А. П. Загнітко. Горлівка : ГДПІІМ, 2004. - Ч. 3. - 266 с.

3. Звєрєва О.С. Функціонування парцельованих конструкцій у сучасному російському поетичному мовленні : автореф. дис. ... канд. філол. наук / О. С. Звєрєва. - К., 1998. - 16 c.

4. Конюхова Л. І. Явище парцеляції в мові сучасних засобів масової комунікації : автореф. дис. ... канд. філол. наук / Л. І. Конюхова. - Львів, 1999. - 15 с.

5. Покальчук Ю. В. Час прекрасний : Повісті та оповідання / Ю. В. Покальчук. Х. : Фоліо, 2002. - 653 c.

6. Самбук Р. Тайна вечеря : [роман] / Р. Самбук. - К. : Укр. письменник, 1992. - 158 с.

7. Самчук У. Марія. Куди тече та річка: [романи] / У. Самчук. - К. : Наукова думка, 2003. $-416 \mathrm{c}$.

8. Сковородников А. П. О функциях парцелляции в современном русском литературном языке / А. П. Сковородников // Русский язык в школе. - 1980. - № 5. C. 86-91.

Стаття надійшла до редакиіï 23.06.2015 p. 